\title{
PENGEMBANGAN KURIKULUM PAI \\ BERBASIS MULTIKULTURAL \\ (Perspektif Psikologi Pembelajaran)
}

\author{
Achmad Yusuf \\ Achysf@yudharta.ac.id \\ Universitas Yudharta Pasuruan
}

\begin{abstract}
The curriculum is like a house that must have a foundation in order to stand tall, not collapse and can provide comfort for those who live in it from diverse backgrounds, the foundation is the foundation of the curriculum as his home, in order to provide comfort and convenience for students to study and make products that are useful for themselves, religion, society and country.

Learning theories that underlie curriculum development include the following: (a) Power Psychology, (b) State mental theory, (c) Psychology of Behaviorism, (d) Theory of Connectionsism, (e) Gestalt Psychology, (f) Constructivism Learning Theory, and (g) Jean Piaget's Cognitivism Development Theory.
\end{abstract}

Keywords: Multicultural Based Curriculum, PAI

\section{PENDAHULUAN}

Kurikulum sebagai pedoman dalam mencapai tujuan dalam pendidikan memiliki posisi yang cukup sentral dalam seluruh kegiatan pendidikan dalam menentukan proses pelaksanaan dan hasil dalam pendidikan. Mengingat begitu pentingnya peranan kurikulum dalam pendidikan terhadap kehidupan manusia, maka pengembangan kurikulum tidak dapat dirancang sembarangan dengan tanpa memperhatikan landasan dalam pengembangan kurikulum.

Kurikulum ibarat sebuah rumah yang harus mempunyai pondasi agar dapat berdiri tegak kuat, tidak roboh dan dapat memberikan kenyamanan bagi yang tinggal di dalamnya dari latar belakang yang beragam, pondasi tersebut adalah landasan-landasan kurikulum sebagai rumahnya, agar bisa memberikan kenyamanan dan kemudahan bagi siswa untuk menuntut ilmu dan menjadikannya produk yang berguna bagi dirinya sendiri, agama, masyarakat dan negaranya. Bila landasan/pondasi rumahnya lemah, maka 


\section{2 ][ Pengembangan Kurikulum PAl Berbasis Multikultural}

akan menyebabkan rumahnya ambruk, sedangkan jika landasan kurikulum yang lemah dalam pendidikan maka yang ambruk adalah manusianya.

Berkaitan dengan hal tersebut, dalam mengembangkan kurikulum khususnya Pendidikan Agama Islam membutuhkan landasan yang didasarkan pada hakikat manusia itu sendiri, agar perancangan dalam pengembangan kurikulum sesuai dengan potensi yang dimiliki setiap individu. Salah satu landasan yang berkaitan dengan pengembangan kurikulum adalah landasan psikologis, yaitu landasan yang mengacu dan didasarkan pada aspek individu siswa itu sendiri yang didalamnya memiliki potensi (keunikan), latarbelakang, bahasa, agama, suku dan ras berbeda-beda yang dikembangkan, dihargai, dan dihormati. Adanya latarbelakang yang beragam tersebut dapat berimplikasi pada tipe/gaya belajar siswa yang berbeda-beda, sebab siswa dalam proses pendidikan merupakan seorang individu yang sedang berada dalam proses perkembangan baik itu fisik, intelektual, social emosional, moral, mental, dan sebagainya.

Oleh karena itu untuk menjawab persoalan tersebut, pengembangan kurikulum Pendidian Agama Islam yang lebih efektif serta agar dapat terlaksana dengan baik dalam mencapai tujuan kurikulum selain didasarkan pada landasan filosofis, juga didasarkan pada landasan psikologis agar dalam pengembangan kurikulum Pendidikan Agama Islam yang akan dilaksanakan relevan dengan hakikat peserta didik, baik penyesuaian dari segi materi/bahan yang harus diberikan/dipelajari peserta didik, maupun dari segi penyampaian dan proses belajar serta penyesuaian dari unsur-unsur upaya pendidikan lainnya. Berdasarkan uraian di atas, tulisan ini membahas tema tentang Dasar Psikologis dalam Pengembangan Kurikulum PAI Berbasis Multikultural yaitu;

1. Landasan Psikologi belajar siswa dalam pengembangan Kurikulum PAI Multikultural;

2. Langkah-langkah Pengembangan Kurikulum PAI Berbasis Multikultural;

3. Desain Pengembangan Kurikulum PAI Multikultural berlandaskan psikologi belajar siswa.

\section{PEMBAHASAN}

\section{A. Landasan Psikologis Dalam Pengembangan Kurikulum}

Nana Syaodih Sukmadinata mengemukakan bahwa minimal terdapat dua bidang psikologi yang mendasari pengembangan kurikulum yaitu (1) psikologi perkembangan dan (2) psikologi belajar.Psikologi 
perkembangan merupakan ilmu yang mempelajari tentang perilaku individu berkenaan dengan perkembangannya. Dalam psikologi perkembangan dikaji tentang hakekat perkembangan, pentahapan perkembangan, aspek-aspek perkembangan, tugas-tugas perkembangan individu, serta hal-hal lainnya yang berhubungan perkembangan individu, yang semuanya dapat dijadikan sebagai bahan pertimbangan dan mendasari pengembangan kurikulum.

\section{Psikologi Perkembangan}

Anak merupakan individu yang berada dalam proses pertumbuhan dan perkembangan. Proses pertumbuhan dan berkembang dimulai sejak konsepsi sampai berakhirnya masa remaja. Anak menunjukkan ciri-ciri pertumbuhan dan perkembangan yang sesuai dengan usia.

Secara bahasa, perkembangan adalah proses menjadi bertambah sempurna (kepribadian, pikiran, pengetahuan dan lainlain) ${ }^{1}$ Sedangkan menurut istilah, perkembangan adalah proses perubahan yang berkesinambungan dan saling berhubungan yang terjadi pada setiap makhluk hidup, menuju kesempurnaan kematangannya. ${ }^{2}$ Menurut J.P Chaplin perkembangan juga memiliki arti yang sama dengan pertumbuhan. ${ }^{3}$ Namun, kata pertumbuhan biasanya sering diartikan sebagai proses perubahan kuantitatif dari perubahan fisik. Adapun yang dimaksud dengan peserta didik adalah anggota masyarakat yang berusaha mengembangkan dirinya melalui proses pendidikan pada jalur, jenjang, dan jenis pendidikan tertentu. ${ }^{4}$

Berdasarkan beberapa uraian di atas, perkembangan peserta didik adalah proses perubahan fungsi-fungsi jasmani dan psikis (sosial, kepribadian, pikiran, pengetahuan dan lain sebagainya) peserta didik yang berkesinambungan dan berhubungan menuju kesempurnaan kematangannya.

\footnotetext{
1 TIM Badan Pembinaan dan Pengembangan Bahasa, Kamus Bahasa Indonesia Untuk Pelajar, 224

${ }^{2}$ Muhammad Hashim al-Faluqi>, Al-Manhaj Al-Ta'limiyyah, 208.

3 J.P. Chaplin, Kamus Lengkap Psikologi, diterjemahkan oleh Kartini Kartono (Jakarta: Rajawali, 1989), 134

${ }^{4}$ Undang-Undang Republik Indonesia Nomor 2 Tahun 1989 Tentang Sistem Pendidikan Nasional Bab I Ketentuan Umum Pasal 1. Lihat juga pada Peraturan Pemerintah Republik Indonesia Nomor 19 Tahun 2005 Tentang Standar Nasional Pendidikan Pasal 1
} 
Fase perkembangan adalah penahapan atau periodeisasi rentang kehidupan manusia yang ditandai oleh ciri-ciri atau pola tingkah laku tertentu. Berdasarkan hasil penelitian para ahli terlihat bahwa dasar yang digunakan untuk mengkaji periodeisasi perkembangan anak ternyata berbeda-beda. Secara garis besarnya terdapat empat dasar pembagian fase-fase perkembangan ini, yaitu: (1) fase perkembangan berdasarkan ciri-ciri biologis, (2) konsep didaktis, (3) ciri-ciri psikologis, dan (4) konsep tugas perkembangan. ${ }^{5}$

Adapun periodeisasi perkembangan peserta $\operatorname{didik}^{6}$ sebagai berikut;

\section{a. Periodeisasi Perkembangan Berdasarkan Ciri-ciri Biologis}

1) Aristoteles (384-322 S.M)

Ia membagi masa periodeisasi perkembangan selama 21 tahun dalam 3 masa, yaitu: (1) Fase anak kecil (0-7 tahun), fase ini diakhiri dengan pergantian gigi. (2) Fase anak sekolah (7-14 tahun), fase ini dimulai dari tumbuhnya gigi baru sampai timbulnya gejala berfungsinya kelenjar-kelenjar kelamin. (3) Fase remaja (pubertas) 14-21 tahun, disebut masa peralihan diri anak menjadi orang dewasa. Fase ini dimulai dari bekerjanya kelenjar-kelenjar kelamin sampai akan memasuki masa dewasa.

2) Maria Montessori

Menurut Maria, pembagian fase-fase perkembangan meliputi: (1) Periode I (0-7 tahun), yaitu periode penangkapan dan pengenalan dunia luar dengan paca indra. (2) Periode II (7-12 tahun), yaitu periode abstrak dimana anak-anak mulai menilai perbuatan manusia atas dasar baik dan buruk. (3) Periode III (12-18 tahun), yaitu periode penemuan diri dan kepekaan sosial. (4) Periode IV (18 keatas), yaitu periode pendidikan tinggi.

3) Elizabeth B. Hurlock

Elizabeth B. Hurlock membagi perkembangan individu berdasarkan konsep biologis atas 5 fase, yaitu: (1) Fase prenatal (sebelum lahir), mulai konsepsi sampai proses

\footnotetext{
${ }^{5}$ Desmita, Psikologi Perkembangan Peserta Didik, 20.

${ }^{6}$ Ibid, hal. 20
} 
kelahiran. (2) Fase infancy (orok/masa kecil), mulai lahir sampai usia 14 hari. (3) Fase babyhood (bayi), mulai dari 2 minggu sampai sekitar umur 2 tahun. (4) Fase childhood (anak-anak), mulai usia 2 tahun sampai usia pubertas. (5) Fase adolessence (remaja), mulai usia 11 tahun sampai usia 21 tahun, yang dibagi atas tiga masa: 5.1. Fase pre adolescence: mulai usia 11 dan 13 tahun untuk wanita dan usia sekitar setahun kemudian untuk laki-laki. 5.2. Fase early adolescence: mulai dari usia 13-14 tahun sampai 16-17 tahun 5.3. Fase late adolescence: masa-masa akhir dari perkembangan seseorang atau hampir bersamaan dengan masa ketika seseorang tegah menempuh perguruan tinggi.

\section{Fase Perkembangan Berdasarkan Konsep Didaktis}

Dasar yang digunakan untuk menentukan pembagian fase ini adalah materi dan cara mendidik anak pada masa-masa tertentu. Pembagian ini diantaranya dikemukakan oleh Johann Amos Comenius (seorang ahli pendidikan di Moravia). Pembagian tersebut adalah:

a. 0-6 tahun : sekolah ibu, merupakan masa mengembangkan alat alat indra dan memperoleh pengetahuan dasar di bawah asuhan ibu

b. 6-12 tahun : sekolah anak, merupakan masa anak mengembangkan daya ingatanya dibawah pendidikan sekolah rendah.

c. 12-18 tahun : sekolah bahasa Latin (sekolah remaja), merupakan masa mengembangkan daya pikirannya dibawah pendidikan sekolah menengah. Pada masa ini mulai diajarkan bahasa latin sebagai bahasa asing.

d. 18-24 tahun: sekolah tinggi dan pengembaraan, merupakan masa mengembangkan kemaunnya dan memilih suatu lapangan hidup yang berlangsung di bawah perguruan tinggi.

\section{Periodeisasi Perkembangan Berdasarkan Ciri-ciri Psikologis}

Periodeisasai perkembangan psikologis didasarkan atas ciri-ciri kejiwaan yang menonjol pada manusia. Periodeisasi ini dikemukakan oleh beberapa ahli, diantaranya ${ }^{7}$

1) Oswald Kroh

${ }^{7}$ Desmita, Psikologi Perkembangan Peserta Didik, 24. 
Ciri-ciri psikologis yang digunakan sebagai dasar oleh Oswald Kroh adalah pandangannya terhadap anak-anak yang umumnya memiliki keguncangan jiwa yang dimanifestasikan dalam bentuk sifat trotz (keras kepala). Atas dasar ini ia membagi masa perkembangan dalam 3 fase, yaitu: (1) Fase anak awal: Dari lahir (0-3 tahun). Pada akhir fase ini terjadi trotz pertama, yang ditandai dengan anak serba membantah atau menentang. (2) Fase keserasian sekolah: dari umur 3-13 tahun. Pada akhir masa ini timbul sifat trotz kedua, dimana anak suka menentang kepada orang lain, terutama kepada orang tuanya. (3) Fase kematangan: anak berumur 14-19 tahun. Pada fase ini anak mulai menyadari kekurangannya dan kelebihannya, yang dihadapi dengan sikap sewajarnya.

2) Kohnstamm

Kohnstamm membagi fase perkembangan manusia menjadi 5 fase, yaitu: (1) Periode vital: umur 0-1,5 tahun, disebut juga fase menyusui. (2) Periode estetis: umur 1,5-7 tahun, disebut juga fase pencoba dan bermain. (3) Periode intelektual (fase sekolah): umur 7-14 tahun. (4) Periode sosial (remaja): umur 14-21 tahun. (5) Periode matang: umur 21 tahun keatas, disebut juga masa tua

3) Erik Erikson

Tahapan perkembangan psikosoial ini menekankan perubahan perkembangan psikososial sepanjang siklus kehidupan manusia. Berikut delapan tahapan perkembangan manusia ditinjau dari segi psikososial:

(1) Percaya versus tidak percaya (0-1 tahun)

Pada tahap ini bayi sudah terbentuk rasa percaya kepada seseorang baik orang tua maupun orang yang mengasuhnya ataupun perawat yang merawatnya, kegagalan pada tahap ini apabila terjadi kesalahan dalam mengasuh atau merawat maka akan timbul rasa tidak percaya.

(2) Tahap otonomi versus rasa malu dan ragu (1-3 tahun)

Anak sudah mulai mencoba dan mandiri dalam tugas tumbuh kembang seperti dalam motorik kasar: anak mampu berjinjit, memanjat, berbicara dan lain sebagainya, sebaliknya perasaan malu dan ragu akan timbul apabila anak merasa dirinya terlalu dilindungi atau tidak diberikan atau kebebasan anak dan menuntut tinggi harapan anak 
(3) Tahap inisiatif versus rasa bersalah (3-6 tahun )

Anak akan mulai inisiatif dalam belajar mencari pengalaman baru secara aktif dalam melakukan aktifitasnya melalui kemampuan indranya. Hasil akhir yang diperoleh adalah kemampuan untuk menghasilkan sesuatu sebagai prestasinya. Apabila dalam tahap ini anak dilarang atau dicegah maka akan timbul rasa bersalah pada diri anak.

(4) Tekun versus rasa rendah diri (6-12 tahun)

Anak akan belajar untuk bekerjasama dan bersaing dalam kegiatan akademik maupun dalam pergaulan melalui permainan yang dilakukan bersama. Anak selalu berusaha untuk mencapai sesuatu yang diinginkan sehingga anak pada usia ini rajin dalam melakukan sesuatu. Apabila dalam tahap ini anak terlalu mendapat tuntutan dari lingkunganya dan anak tidak berhasil memenuhinya maka akan timbul rasa inferiorty ( rendah diri ).

(5) Tahap identitas dan kebingungan identitas ( 12-20 tahun)

Pada tahap ini terjadi perubahan dalam diri anak khususnya dalam fisik dan kematangan usia, perubahan hormonal, akan menunjukkan identitas dirinya seperti siapa saya kemudian. Apabila kondisi tidak sesuai dengan suasana hati maka dapat menyebabkan terjadinya kebingungan dalam peran.

(6) Keakraban versus keterkucilan (20-30 tahun)

Individu menghadapi tugas perkembangan relasi intim dengan orang lain. Saat anak muda membentuk persahabatan yang sehat dan relasi akrab dengan oranglain, maka keintiman akan tercapai, namun bila tidak maka akan terjadi isolas.

(7) Generativitas versus stagnasi ( 40-50 tahun )

Pada fase ini, seseorang akan memiliki perhatian terhadap apa yang dihasilkan, keturunan, serta ide untuk generasi mendatang. Namun, jika generativitas lemah, maka akan terjadi stagnasi.

(8) Integritas diri versus keputusasaaan ( 50 tahun keatas)

Pada fase ini, seseorang akan mengevaluasi apa yang telah dilalakukannya selama ia hidup. Jika manusia usia lanjut mampu memelihara dan menyesuaikan diri dengan keberhasilan, maka ia akan merasa sukses. Namun, jika ia menyelesaikan hanya tahap sebelumnya secara negatif, maka cenderung akan menghasilkan 
rasa bersalah atau kemurangan yang disebut Erikson sebagai despair (putus asa).

\section{PSIKOLOGI BELAJAR}

\section{Pengertian Belajar}

Belajar merupakan key term (istilah kunci) yang paling penting dalam pendidikan. Dapat dikatakan bahwa tanpa belajar, sesungguhnya tak pernah ada pendidikan. Karena demikian pentingnya belajar maka tidak heran bila masalah-masalah belajar terus menjadi kajian menarik bagi banyak ahli pendidikan.

Ratumanan mendefinisikan belajar merupakan suatu kegiatan mental yang tidak dapat diamati dari luar. Apa yang terjadi dalam diri seseorang tidak dapat diketahui secara langsung hanya mengamati orang tersebut. Hasil belajar hanya bisa diamati, jika seseorang menampakkan kemampuan yang telah diperoleh melalui belajar. Karenanya, berdasarkan perilaku yang ditampilkan, dapat ditarik kesimpulan bahwa seseorang telah belajar. ${ }^{8}$ Selanjutnya Winkel mendefinisikan belajar adalah suatu aktivitas mental/psikis yang berlangsung dalam interaksi aktif dengan lingkungan yang menghasilkan perubahan-perubahan dalam pengetahuan, pemahaman, ketrampilan, dan nilai sikap. ${ }^{9}$

Menurut Robert M. Gagne dalam bukunya The Conditioning of Learning mengemukakan bahwa Learning is a change in human disposition or capacity, which persist over a period time, and which is not simply ascribable to process of growth. Pendapat itu diartikan bahwa belajar adalah perubahan yang terjadi dalam kemampuan manusia setelah belajar terus-menerus, bukan hanya disebabkan oleh proses pertumbuhan saja. Gagne berkeyakinan bahwa belajar dipenagaruhi oleh faktor dari luar diri dan faktor dalam diri dan keduanya saling berinteraksi. ${ }^{10}$

Menurut James O. Whittaker, belajar dapat didefinisiskan sebagai proses dimana tingkah laku ditimbulkan atau diubah melalui latihan atau

\footnotetext{
8 Tanwey Gerson Ratumanan, Belajar dan Pembelajaran, (Surabaya: Unesa University Press, 2004), h.1

${ }^{9}$ Winkel, W. S. Psikologi Pengajaran, (Jakarta: Grasindo, 1989), h.36

${ }^{10}$ Bambang Warsita, 2008, "Teori Belajar M. Gagne dan Implikasinya pada Pentingnya Pusat Sumber Belajar", Jurnal Teknodik, vol. XII, no. 1, hal. 66
} 
pengalaman. "Learning may be defined as the process by which behavior originates or altered through training or experience" ${ }^{11}$.

Tidak jauh beda dengan pendapat W. H Burton dalam bukunya The Guidance of Learning activities, 1984, yang menyatakan bahwa belajar dapat diartikan sebagai perubahan tingkah laku pada diri individu dengan lingkungannya. "learning is a change in the individual due to instruction of that individual and his environment, which fells a need and makes him more capable of dealing adequately with his environment". ${ }^{12}$

Belajar merupakan proses yang memungkinkan manusia memodifikasi tingkah lakunya secara permanen, sedemikian hingga modifikasi yang sama tidak akan terjadi lagi pada situasi baru. Pengamat akan mengetahui tentang terjadinya proses belajar pada orang yang diamati bila pengamat itu memperhatikan terjadinya perubahan tingkah laku. Kematangan menurut Gagne, bukanlah belajar, sebab perubahan tingkah laku yang terjadi, dihasilkan dari pertumbuhan struktur dan diri manusia itu. Dengan demikian belajar terjadi bila individu merespons terhadap stimulus yang datangnya dari luar, sedangkan kematangan datangnya memang dari dalam diri orang itu. Perubahan tingkah laku yang tetap sebagai hasil belajar harus terjadi bila orang tersebut berinterkasi dengan lingkungan.

\section{Teori Belajar}

Teori belajar ini sangat membantu pengajar dalam menyampaikan bahan pelajaran kepada peserta didik. Dengan memahami teori belajar, pengajar akan memahami proses terjadinya belajar manusia. Pengajar dalam hal ini guru mengerti bagaimana seharusnya memberikan stimulasi sehingga peserta didik menyukai belajar. Dalam psikologi belajar dikenal dengan istilah aliran, yang mana dari setiap aliran tersebut memiliki teori yang berimplikasi terhadap pengembangan kurikulum. ${ }^{13}$ Sebagaimana menurut Hidayat sebagai berikut:

a. Psikologi Daya

Pandangan ini menyatakan bahwa setiap manusia memiliki daya seperti daya mengingat, berpikir, merasakan, berkehendak, dan

\footnotetext{
${ }^{11}$ Abu Ahmadi dan Widodo Supriyono, Psikologi Belajar, (Jakarta: Rineka Cipta, 2004), h. 126

${ }^{12}$ Ibid

${ }^{13}$ Sholeh Hidayat, Pengembangan Kurikulum Baru. Hal. 37
} 
sebagainya. Implikasi terhadap pengembangan kurikulum adalah kurikulum harus menyediakan berbagai mata pelajaran yang dapat mengoptimalkan dan mengembangkan daya yang dimiliki oleh setiap individu. Penekanan bukan terletak pada materinya, akan tetapi pada peran mata pelajaran dalam membentuk daya-daya tersebut. Kurikulum di susun untuk semua siswa, tanpa memerhatikan isi, minat, dan kebutuhan siswa. ${ }^{14}$

b. Teori mental State

Menurut J. Herbat yang dikutip oleh Hamalik, jiwa manusia sesungguhnya terdiri dari atas berbagai kesan atau tanggapan yang masuk melalui alat indra, berasosiasi satu sama lain untuk membentuk mental atau kesadaran manusia. Implikasi terhadap kurikulum disusun dari sejumlah mata pelajaran yang mengandung pengetahuan yang luas yang disusun secara terpisah satu sama lainnya akan tetapi berasosiasi dalam mental siswa.

1) Psikologi Behaviorisme

Aliran ini berpandangan bahwa kesan dan ingatan merupakan kegiatan organism manusia yang tidak dapat diamati, akan tetapi tingkah laku jasmaninya yang dapat di amati yang merupakan gambaran tentang apa yang dipikirkan dalam jiwa manusia. Menurut Sugiyono ciri-ciri dalam toeri ini adalah (1) mengutamakan unsureunsur atau bagiat-bagian kecil, (2) bersifat mekanistis, (3) menekankan peranan lingkungan, (4) mementingkan pembentukan lingkungan, dan (5) menekankan pentingnya latihan. ${ }^{15}$ Implikasi terhadap kurikulum adalah penyusunannya dengan mempelajari kelakuan manusia. ${ }^{16}$

2) Teori Koneksionisme

Teori ini berdasar pada psikologi behaviorisme doktrin pokok teori ini adalah hubungan stimulus respon. Teori ini berpandangan bahwa lingkungan dapat mempengaruhi kelakuan belajar individu sedangkan kelakuan motivasi bersifat mekanis, disamping itu lebih mengutamakan pengalaman masa lalu dan kurang memerhatikan

\footnotetext{
${ }^{14}$ Oemar Hamalik. Dasar-Dasar pengembangan Kurikulum. (Bandung: Remaja Rosdakarya, 2013), hal. 107

15 Sugiyono dkk, Belajar dan Pembelajaran: Teori dan Praktik. (Bandung: Remaja Rosdakarya 2011), hal. 58

${ }^{16}$ Oemar Hamalik. Dasar-Dasar pengembangan ..Op.Cit. hal.108
} 
proses pengenalan dan berpikir. Implikasi terhadap kurikulum adalah penyusunannya berdasarkan lingkungan yang dapat menimbulkan respon yang diharapkan baik yang bersifat mekanis atau otomatis. ${ }^{17}$

3) Psikologi Gestalt

Aliran ini berpandangan bahwa keseluruan bukanlah penjumlahan bagian-bagian akan tetapi satu kesatuan yang bermakna. Prinsip belajar dari teori ini adalah (a) belajar dimulai dari suatu keseluruhan menuju bagian-bagian tersebut, (b) keseluruhan memberikan makna kepada bagian-bagian tersebut, (c) bagian-bagian dilihat dalam hubungan keseluruhan berkat individuasi, (d) belajar memerlukan pemahaman, (d) belajar memerlukan reorganisasi pengalaman yang kontinu. Implikasinya, kurikulum disusun berdasarkan keseluruhan yang memungkinkan siswa berinteraksi dengan lingkungan dan menimbulkan pemahaman kepada mereka. ${ }^{18}$

4) Teori Belajar Konstruktivisme

Sebagaimana menurut Ima yang dikutip oleh Hasyim menyatakan bahwa siswa harus menemukan sendiri dan mentransformasikan informasi konflik, mengecek informasi baru dengan aturan-aturan lama dan merevisinya apabila aturan-aturan itu tidak logis, dalam hal ini pendidik tidak hanya sekedar memberikan pengetahuan saja, akan tetapi memberikan peluang dan kesempatan kepada siswa untuk menemukan dan menkonstruksi pengetahuan yang diperoleh sehingga pengetahuan tersebut dapat dibangun dari siswa sendiri. ${ }^{19}$

5) Teori Perkembangan Kognitivisme

Teori ini berpandangan bahwa perkembangan kognitif sebagai proses dimana anak secara aktif membangun system makna dan pemahaman realitas melalui pengalaman-pengalaman dan interaksiinteraksinya. ${ }^{20}$ Menurut Piaget setiap anak mengemebangkan kemampuan berpikirnya berdasarkan tahapan yang teratur, dalam hal ini ada empat tahap perkembangan kognitif $^{21}$, yaitu;

\footnotetext{
${ }^{17}$ Ibid, hal. 108

${ }^{18}$ Ibid, hal.109

${ }^{19}$ Farid Hasyim. Kurikulum Pendidikan Agama Islam: Filosofis Pengembangan Kurikulum Transformatif antara KTSP dan Kurikulum 2013. (Malang: Madani. 2013), hal. 80

${ }^{20}$ Ibid

${ }^{21}$ Sugiyono dkk, Belajar dan Pembelajaran....Op.Cit. hal 83
} 
a) Tahap sensory motor (berlangsung sejak lahir sampai sekitar 2 tahun)

b) Tahap Pra Operational (usia 2-7 tahun)

c) Tahap Operasional Konkret (usia 7-11 tahun)

d) Tahap Operasional Formal (usia 11 sampai dewasa)

Implikasi teori kognitif ini terhadap pembelajaran adalah; (1) bahasa dan cara berpikir anak berbeda dengan orang dewasa, (2) anak-anak akan belajar lebih baik apabila dapat menghadapi lingkungan dengan baik, (3) bahan yang di pelajari harus hendaknya dirasakan sebagai bahan baru tetapi tidak asing, dan (4) berikan kesempatan untuk belajar sesuai dengan tapa perkembangannya.

\section{Gaya/Tipe Belajar}

Para ahli dalam bidang pendidikan mencoba mengembangkan teori mengenai gaya belajar sebagai cara untuk mencari jalan agar belajar menjadi hal yang mudah dan menyenangkan. Belajar juga membutuhkan konsentrasi. Selain itu, situasi dan kondisi untuk berkonsentrasi sangat berhubungan dengan gaya belajar siswa. Jika siswa dapat mengenali gaya belajarnya, maka ia dapat mengelola dalam berbaga kondisi belajar. Istilah gaya belajar berlaku pada segala sesuatu yang mempengaruhi cara kita belajar.

Bobbi DePorter dalam Quantum Learning mendefinisikan bahwa modalitas (gaya) belajar adalah cara termudah bagi individu dalam menyerap informasi. ${ }^{22}$ selanjutnya Gaya belajar merupakan suatu sikap pribadi yang cenderung menetap dalam mempersepsikan suatu stimulus tertentu dari lingkungan selanjutnya memanfaatkannya secara unik dan personal dalam berinteraksi dengan stimulus maupun sumber stimulus. Perilaku yang ditampilkan cenderung menetap selama minat individu tidak berubah. ${ }^{23}$ Sedangkan menurut Nasution Gaya Belajar adalah cara ia (siswa) bereaksi dan menggunakan perangsang-perangsang yang diterimanya dalam proses belajar. ${ }^{24}$

\footnotetext{
${ }^{22}$ Bobby DePorter dan Mike Hernacki, Quantum Learning: Membiasakan Belajar Nyaman dan Menyenangkan. . . , hal. 111

${ }^{23}$ Sia Tjundjing, "Keandalan VARK: Instrumen Modalitas Belajar Baru yang Unik dan Menarik",Anima, Indonesian Psychological Journal (Vol. 18, No. 4, Juli 2003), 342-343

${ }^{24}$ Nasution, Berbagai Pendekatan dalam Proses Belajar dan Mengajar (Jakarta: Bumi Aksara,

2006), 93.
} 
Dari beberapa pendapat parah ahli, dapat ketahui bahwa gaya belajar adalah cara, langkah, atau strategi yang digunakan oleh siswa untuk memperoleh dan mengkontruksi pengetahuan dari informasi yang diterima dilinkungan belajarnya.

\section{a. Faktor yang mempengaruhi Gaya Belajar}

Faktor-faktor yang mempengaruhi gaya belajar menurut Joko Susilo yaitu:

1) Faktor alamiah (pembawaan): ada hal-hal tertentu yang tidak dapat diubah dalam diri seseorang bahkan dengan latihan sekalipun.

2) Faktor lingkungan: ada juga hal-hal yang dapat dilatihkan dan disesuaikan dengan lingkungan yang terkadang justru tidak dapat diubah. $^{25}$

Sedangkan menurut Gordon Dryden dan Dr. Jeannette Vos, faktor-faktor yang mempengaruhi gaya belajar seseorang adalah:

1) Lingkungan fisik: suara, cahaya, suhu, tempat duduk, sikap tubuh sangat berpengaruh pada proses belajar seseorang.

2) Kebutuhan emosional: orang juga memiliki berbagai kebutuhan emosional. Dan emosi berperanan penting dalam proses belajar. Dalam banyak hal, emosi adalah kunci bagi sistem memori otak. Muatan emosi dari presentasi dapat berpengaruh besar dalam memudahkan pelajar untuk menyerap informasi dan ide.

3) Kebutuhan sosial: sebagian orang suka belajar sendiri. Yang lain lebih suka bekerja bersama seorang rekan. Yang lain lagi, bekerja dalam kelompok. Sebagian anak-anak menginginkan kehadiran orang dewasa atau senang bekerja dengan orang dewasa saja.

4) Kebutuhan Biologis: waktu makan, tingkat energi dalam sehari, dan kebutuhan mobilitas juga dapat mempengaruhi kemampuan belajar. $^{26}$

Dari uraian diatas dapat disimpulkan bahwa gaya belajar seseorang dipengaruhi oleh lima faktor, yaitu lingkungan fisik, kebutuhan emosional, kebutuhan sosial, kebutuhan biologis, serta faktor alamiah (pembawaan) dan lingkungan.

${ }^{25}$ Joko Susilo, Gaya Belajar Menjadikan Makin Pintar (Yogyakarta: Pinus, 2006), hal.98

${ }^{26}$ Gordon Dryden,dkk, Revolusi Cara Belajar (The Learning Revolution) Belajar akan Efektif Kalau Anda dalam Keadaan "Fun” (Bandung: Kaifa, 2001), 351 


\section{b. Macam-Macam Gaya Belajar}

Dalam buku Quantum Learning, gaya belajar dibagi menjadi tiga macam, yaitu gaya belajar Visual, gaya belajar Auditorial, dan gaya belajar Kinestetik. Gaya belajar Visual adalah belajar dengan cara melihat. Gaya belajar Auditorial adalah belajar dengan cara mendengar. Sedangkan gaya belajar Kinestetik adalah belajar dengan cara bergerak, bekerja, dan menyentuh. ${ }^{27}$

Sebuah penelitian ekstensif, khususnya di Amerika Serikat, yang dilakukan oleh Profesor Ken dan Rita Dunn dari Universitas St. John, di Jamaica, New York, dan para pakar Pemrograman NeuroLinguistik seperti Richard Bandler, John Grinder, dan Michael Grinder telah mengidentifikasi tiga gaya belajar dan komunikasi yang berbeda, yaitu;

1) Visual : Belajar melalui melihat sesuatu. Individu suka melihat gambar atau diagram. Individu suka pertunjukkan, peragaan atau menyaksikan video.

2) Auditorial : Belajar melalui mendengan sesuatu. Individu suka mendengarkan kaset audio, ceramah-kuliah, diskusi, debat dan instruksi (perintah) verbal.

3) Kinestetik : Belajar melalui aktivitas fisik dan keterlibatan langsung. Individu "suka" menangani, bergerak, menyentuh dan merasakan/mengalami sendiri. ${ }^{28}$

\section{PENDIDIKAN AGAMA ISLAM MULTIKULTURAL}

Pendidikan multicultural Menurut Tilaar, berawal dari berkembangnya gagasan dan kesadaran tentang "interkulturalisme" sesuai Perang Dunia (PD) kedua, perkembangan politik internasional menyakut HAM, kemerdekaan sari kolonialisme, dan diskriminasi rasial, dan juga karena meningkatnya pluralitas (keberagaman). ${ }^{29}$ Ada beberapa pendapat para ahli tentang pengertian pendidikan multicultural yaitu;

Menurut James. A. Banks pendidikan multikultural adalah konsep atau ide sebagai rangkaian kepercayaan dan penjelasan yang mengakui dan

\footnotetext{
${ }^{27}$ Bobbi DePorter, dkk, Quantum Learning..., 113

${ }^{28}$ Colin Rose,dkk, Accelerated Learning for $21^{\text {st }}$ Century (Bandung: Nuansa, 2002), 130131

${ }^{29}$ H.A.R. Tilaar, Perubahan Sosial dan Pendidikan: Pengantar Pedagogik Transformativ untuk Indonesia (Jakarta: Grasindo, 2003)
} 
menilai pentingnya keragaman budaya dan etnis dalam membentuk gaya hidup pengalaman social identitas pribadi dan keksempatan-kesempatan pendidikan dari individu, kelompok maupun Negara. ${ }^{30}$ Selanjutnya menurut Azra mendefinisikan pendidikan multikultural sebagai pendidikan untuk atau tentang keragaman kebudayaan dalam merespon perubahan demografi dan kultur lingkunagn masyarakat tertentu bahkan demi secara keseluruhan. ${ }^{31}$ Pendidikan multikultural merupakan konsep, ide atau falsafah sebagai suatu rangkaian kepercayaan (set of believe) dan penjelasan yang mengakui dan menilai pentingnya keragaman budaya dan etnis dalam membentuk gaya hidup, pengalaman sosial, identitas pribadi, kesempatan-kesempatan pendidikan dari individu, kelompok maupun negara. ${ }^{32}$

Dalam pengertian lain, pendidikan multikultural merupakan suatu cara dalam mengajarkan keragaman (teaching diversity). Pendidikan multicultural menghendaki rasionalitas etis, intelektual, sosial dan pragmatis secara inter-relatif, yaitu mengajarkan ideal-ideal inklusivisme, pluralisme, hubungan antar agama dan saling menghargai semua orang, keragaman kebudayaan-dalam perspektif pendidikan multikultural dipandang-merupakan imperatif humanistik yang menjadi prasyarat bagi kehidupan etis dan partisipasi sipil yang beragam, mengintegrasikan studi tentang fakta-fakta, sejarah kebudayaan, nilai- nilai, struktur, perspektif, dan kontribusi semua kelompok ke dalam kurikulum, sehingga diharapkan dapat membangun pengetahuan yang lebih kaya, kompleks dan akurat tentang kondisi kemanusiaan di dalam dan melintasi konteks waktu, ruang dan kebudayaan tertentu.

Pendidikan multicultural berusaha mengeksplorasi sisi-sisi partikular dan universal dalam cultural studies. Ia berusaha memahami kebudayaankebudayaan dan masyarakat-masyarakat partikular dalam konteks dan dari perspektif mereka sendiri, mengedepankan analisis perbandingan, pemahaman etno-relatif, penilaian yang rasional tentang perbedaan dan persamaan terhadap berbagai kebudayaan dan masyarakat, dan ia berupaya mengidentifikasi ideal-ideal dan praktik- praktik bersama dan universal yang

30 James Banks, Multikultural Education, Dimension, And Practice, (USA: Review Of Research In Education, 1993), h 4

31 mron Mashadi, Pendidikan Agama Islam dalam Perspektif Multikultural, (Jakarta: Balai Litbang Agama, 2009), h 48

${ }^{32}$ A.R. Tilaar, Multikulturalisme, Tantangan-Tantangan Global Masa Depan dalam Transformasi Pendidikan Nasional (Jakarta: PT Grasindo, 2003), hal. 181 


\section{6 ][ Pengembangan Kurikulum PAl Berbasis Multikultural}

melampaui kebudayaan-kebudayaan dan masyarakat-masyarakat partikular, membangun jembatan diantara berbagai kebudayaan serta menyediakan basis bagi hubungan manusiawi. ${ }^{33}$

Pendidikan multikultural menentang semua bentuk asumsi yang belum teruji, bias dan palsu tentang perbedaan dan persamaan manusia, ia merupakan kritik reflektif dan pencarian terhadap isu-isu tersebut untuk membuka jalan terang bagi komunikasi lintas budaya dan bertindak lebih adil dan konstuktif terhadap perbedaan kultural. Karena alasan-alasan praktis dan etis, kini setiap komponen edukatif perlu belajar berkomunikasi, mempelajari hidup dan bekerjasama secara efektif dan damai dengan mereka yang secara kultural berbeda. Dengan pendidikan semacam ini, ending process-nya diharapkan pebelajar dari tingkat sekolah dasar, menengah hingga perguruan tinggi dapat tumbuh dalan suatu dunia yang bebas dari prasangka, bias dan diskriminasi atas nama apapun, baik agama, gender, ras, warna kulit, etnis, kebudayaan, kelas dan sebagainya untuk mencapai suatu tujuan mereka dan merasakan bahwa apapun yang mereka kehendaki untuk dapat terlaksana dalam kehidupan ini menjadi lebih mungkin. ${ }^{34}$

Berdasarkan uraian di atas, jelaslah bahwa pendidikan agama Islam multikultural adalah proses transformasi dan internalisasi nilai-nilai dasar dan ideal ajaran Islam yang berusaha mengaksentuasikan aspek-aspek perbedaan dan disparitas kemanusiaan dalam konteksnya yang luas sebagai suatu grand design of God yang mesti diterima dengan penuh arif dan lapang dada ditengah kenyataan kemanusiaan yang plural-multikultural dalam segala dimensinya guna mewujudkan tatanan kehidupan yang berkeadilan (mardhaatillah).

Dengan definisi yang lebih operasional, dapat dinyatakan bahwa pendidikan agama islam multikultural merupakan usaha komprehensif dalam mencegah terjadinya konflik antar agama, mencegah terjadinya radikalisme agama, sekaligus pada saat yang sama memupuk terwujudnya sikap yang apresiatif positif terhadap pluralitas dalam dimensi dan perspektif apapun, karena pendidikan agama berbasis multikultural memiliki visi dan misi untuk mewujudkan agama pada sisi yang lebih santun, dialogis,

33 Edi Susanto et.al.,Pendidikan Agama Islam Multikultural; Perspektif Kritis atas Pemikiran Nurcholish Madjid (Surabaya: Penerbit eLKAF, 2008), hal. 52

${ }^{34}$ Zakiyuddin Baidhawy, Pendidikan Agama Berwawasan Multikultural, (Jakarta: Erlangga, 2005), hal. 8 
apresiatif terhadap pluralitas dan peduli terhadap persoalan hidup yang komunal transformatif. ${ }^{35}$

\section{LANGKAH-LANGKAH PENGEMBANGAN KURIKULUM PAI BERBASIS MULTIKULTURAL}

Pendidikan agama Islam berbasis multikultural adalah proses transformasi dan internalisasi nilai-nilai dasar dan ideal ajaran Islam yang berusaha mengaksentuasikan aspek-aspek perbedaan dan disparitas kemanusiaan dalam konteksnya yang luas sebagai suatu sunnatullah yang mesti diterima dengan penuh arif dan lapang dada di tengah kenyataan kemanusiaan yang plural dalam segala dimensinya guna mewujudkan tatanan kehidupan yang berkeadilan.

Pendidikan agama islam berbasis multicultural mengusung pendekatan dialogis untuk menanamkan kesadaran hidup bersama dalam keragaman dan perbedaan. Pendidikan ini dibangun atas dasar spirit relasi kesetaraan dan kesederajatan, saling percaya, saling memahami, menghargai persamaan, perbedaan dan keunikan. Ini merupakan inovasi dan reformasi yang integral dan komprehensif dalam muatan pendidikan agama; memberi konstruk pengetahuan baru tentang agama-agama yang bebas prasangka, rasisme, bias dan streotip. Pendidikan agama multikultural memberi pengakuan akan pluralitas, sarana belajar untuk perjumpaan lintas batas, dan mentransformasi indoktrinasi menuju dialog. ${ }^{36}$

Keragaman sosial, budaya, ekonomi, dan aspirasi politik, dan kemampuan ekonomi adalah suatu realita masyarakat dan bangsa Indonesia. Namun demikian, keragaman sosial, budaya, ekonomi, dan aspirasi politik yang seharusnya menjadi faktor yang diperhitungkan dalam penentuan filasafat, teori, visi,pengembangan dokumen, sosialisasi kurikulum, dan pelaksanaan kurikulum, nampaknya belum dijadikan sebagai faktor yang harus dipertimbangkan dalam pelaksanaan kurikulum pendidikan di negara kita. Maka akibatnya, wajar manakala terjadi kegagalan dalam pendidikannya (termasuk pendidikan agama), terutama sekali dalam menumbuhkan sikap-sikap untuk menghargai adanya perbedaan dalam masyarakat.

${ }^{35}$ Edi Susanto et.al, Pendidikan Agama...,Op.cit hal. 52-53

${ }^{36}$ Zakiyuddin Baidhawy, Pendidikan Agama..., Op.cit. hal. 74 


\section{8 ][ Pengembangan Kurikulum PAl Berbasis Multikultural}

Pengembangan kurikulum Pendidikan Agama Islam yang berbasis multikultural dapat dilakukan berdasarkan langkah-langkah sebagai berikut: ${ }^{37}$

1. Mengubah filosofi kurikulum dari yang berlaku seragam seperti saat ini kepada filosofi yang lebih sesuai dengan tujuan, misi, dan fungsi setiap jenjang pendidikan dan unit pendidikan.

2. Teori kurikulum tentang konten (curriculum content), haruslah berubah dari teori yang mengartikan konten sebagai aspek substantive yang berisikan fakta, teori, generalisasi ke pengertian yang mencakup pula nilai moral, prosedur dan keterampilan (skills) yang harus di miliki oleh generasi muda.

3. Teori belajar yang digunakan dalam kurikulum masa depan yang memperhatikan keragaman sosial, budaya, ekonomi, dan politik tidak boleh lagi hanya mendasarkan diri pada teori psikologi belajar yang menempatkan siswa sebagai makhluk sosial, budaya, politik, yang hidup sebagai anggota aktif masyarakat, bangsa, dan dunia yang harus diseragamkan oleh institusi pendidikan.

4. Proses belajar yang dikembangkan untuk siswa haruslah pula berdasarkan proses yang memiliki tingkat isomorphisme yang tinggi dengan kenyataan sosial. Artinya, proses belajar yang mengandalkan siswa belajar secara individualistis dan bersaing secara kompetitif individualistis harus ditinggalkan dan diganti dengan cara belajar kelompok dan bersaing secara kelompok dalam situasi positif. Diharapkan dengan cara demikian, perbedaan antar individu dapat dikembangkan sebagai suatu kekuatan kelompok, dan siswa terbiasa hidup dengan berbagai budaya, social, intelektualitas, ekonomi, dan aspirasi politik.

5. Evaluasi yang digunakan haruslah meliputi keseluruhan aspek kemampuan dan kepribadian peserta didik, sesuai dengan tujuan dan konten yang dikembangkan.

Di samping itu, setelah memperhatikan beberap langkah di atas, untuk kurikulum PAI yang berbasis multicultural, selain aspek kurikulum yang didesain, aspek pendekatan dan pembelajaran pula harus diperhatikan.Bentuk lama dalam pendekatan atau pembelajaran dalam pendidikan agama Islam harus segera diubah dengan model baru yang lebih komunikatif, yang perlu

37 S. Hamid Hasan, Multikultural untuk Penyempurnaan Kurikulum Nasional, Jurnal Pendidikan dan Kebudayaan, 2000. dalam Choirul Mahfud, Pendidikan Multikultural..., hal. 222 
diperhatikan juga adalah aspek perbedaan setiap individu peserta didik harus menjadi titik tekan dalam pembelajaran.

Sebagaimana menurut James A. Banks mengidentifikasi ada lima dimensi pendidikan multikultural yang dapat membantu guru dalam mengimplementasikan beberapa program yang mampu merespon terhadap perbedaan pelajar (siswa), yaitu:

1) Dimensi integrasi isi/materi (content integration).

Dimensi ini digunakan oleh guru untuk memberikan keterangan dengan 'poin kunci' pembelajaran dengan merefleksi materi yang berbeda-beda. Secara khusus, para guru menggabungkan kandungan materi pembelajaran ke dalam kurikulum dengan beberapa cara pandang yang beragam. Salah satu pendekatan umum adalah mengakui kontribusinya, yaitu guru-guru bekerja ke dalam kurikulum mereka dengan membatasi fakta tentang semangat kepahlawanan dari berbagai kelompok. Di samping itu, rancangan pembelajaran dan unit pembelajarannya tidak dirubah. Dengan beberapa pendekatan, guru menambah beberapa unit atau topik secara khusus yang berkaitan dengan materi multikultural.

2) Dimensi konstruksi pengetahuan (knowledge construction).

Suatu dimensi dimana para guru membantu siswa untuk memahami beberapa perspektif dan merumuskan kesimpulan yang dipengaruhi oleh disiplin pengetahuan yang mereka miliki. Dimensi ini juga berhubungan dengan pemahaman para pelajar terhadap perubahan pengetahuan yang ada pada diri mereka sendiri;

3) Dimensi pengurangan prasangka (prejudice reduction).

Guru melakukan banyak usaha untuk membantu siswa dalam mengembangkan perilaku positif tentang perbedaan kelompok. Sebagai contoh, ketika anak-anak masuk sekolah dengan perilaku negatif dan memiliki kesalahpahaman terhadap ras atau etnik yang berbeda dan kelompok etnik lainnya, pendidikan dapat membantu siswa mengembangkan perilaku intergroup yang lebih positif, penyediaan kondisi yang mapan dan pasti. Dua kondisi yang dimaksud adalah bahan pembelajaran yang memiliki citra yang positif tentang perbedaan kelompok dan menggunakan bahan pembelajaran tersebut secara konsisten dan terus-menerus. 
4) Dimensi pendidikan yang sama/adil (equitable pedagogy).

Dimensi ini memperhatikan cara-cara dalam mengubah fasilitas pembelajaran sehingga mempermudah pencapaian hasil belajar pada sejumlah siswa dari berbagai kelompok. Strategi dan aktivitas belajar yang dapat digunakan sebagai upaya memperlakukan pendidikan secara adil, antara lain dengan bentuk kerjasama (cooperatve learning), dan bukan dengan cara-cara yang kompetitif (competition learning).

Dimensi ini juga menyangkut pendidikan yang dirancang untuk membentuk lingkungan sekolah, menjadi banyak jenis kelompok, termasuk kelompok etnik,wanita,dan para pelajar dengan kebutuhan khusus yang akan memberikan pengalaman pendidikan persamaan hak dan persamaan memperoleh kesempatan belajar.

5) Dimensi pemberdayaan budaya sekolah dan struktur sosial (empowering school culture and social structure).

Dimensi ini penting dalam memperdayakan budaya siswa yang dibawa ke sekolah yang berasal dari kelompok yang berbeda. Di samping itu, dapat digunakan untuk menyusun struktur social (sekolah) yang memanfaatkan potensi budaya siswa yang beranekaragam sebagai karakteristik struktur sekolah setempat, misalnya berkaitan dengan praktik kelompok, iklim sosial, latihan-latihan, partisipasi ekstra kurikuler dan penghargaan staff dalam merespon berbagai perbedaan yang ada di sekolah. ${ }^{38}$

Selnajutnya menurut David L. Lavinson yang dikutip oleh Ghony ${ }^{39}$ pendidikan multicultural dapat di implementasikan dengan lima pendekatan. (1) pendekatan yang lebih menekankan pada latarbelakang peserta didik yang memeiliki perbedaan secara cultural (2) pendekatan hubungan antar keragaman budaya manusia (3) pendekatan dengan kajian tunggal yaitu sebuah pendekatan yang digunakan untuk mengkaji secara mendalam dalam membangun kesadaran kritis tentang posisi suatu kelompok masyarakat, (4) pendekatan multicultural dimana guru mengajarkan siswa agar terbiasa menghadapi perbedaan dengan

${ }^{38}$ Banks, J.A..Multicultural Education: Its Effects on Studies' Racial abd Gender Role Attitude" In Handbook of Research on Social Teaching and Learning. (New York.: MacMillan,1993) dalam http://lubisgrafura.wordpress.com/2007/09/10/pembelajaranberbasis-multikultural/

39 Djunaidi Ghony. 'Desain Pengembangan Kurikulum Pendidikan Agama Islam Multikultural (Handbook Program Doktor PAI Multikultural). Malang: UNISMA.hal. 189 
memperhatikan nilai-nilai cultural, dan (5) pendekatan dengan rekonstruksi social, melalui pendekatan ini peserta didik dibantu secara aktif memahami lingkungan kehidupannya, bertanggung jawab atas pendidikan dirinya dan belajar terampil menghadapi perubahan social.

\section{DESAIN PENGEMBANGAN KURIKULUM PAI MULTIKULTURAL BERLANDASKAN PSIKOLOGI BELAJAR SISWA}

Psikologi belajar memberikan sumbangan terhadap kurikulum mengenai pelaksanaan kurikulum di sekolah, yakni melalui strategi belajar mengajar. Psikologi belajar berkenaan proses perubahan tingkah laku manusia itu terjadi. Hal ini diperlukan dalam pendidikan terutama bagi guru dalam melaksanakan pembelajaran, sebab proses belajar mengajar atau pembelajaran pada hakikatnya mengubah tingkah laku baru para peserta didik.

Dalam kaitannya dengan pengembangan Kurikulum PAI Multikultural, psikologi perkembangan diperlukan sebagai dasar pengembangan kurikulum terutama dalam hal penentuan isi kurikulum yang akan diberikan/dipelajari oleh peserta didik, baik tingkat kedalaman dan keluasan materi, tingkat kesulitan dan kelayakan, serta manfaatnya yang disesuaikan dengan tahap dan tugas perkembangan peserta didik. Psikologi belajar dapat memberikan sumbangsih terhadap pengembangan kurikulum PAI Multikultural terutama berkenaan dengan bagaimana kurikulum itu diberikan kepada peserta didik dan bagaimana peserta didik harus mempelajarinya, berarti berkenaan dengan strategi pelaksanaan kurikulum.

Anak sejak dilahirkan sudah memiliki potensi dan sudah memperlihatkan keunikan-keunikan yang berbeda satu sama lainnya, seperti pernyataan dirinya dalam bentuk tangisan dan gerakan-gerakan tubuhnya. Hal ini menggambarkan bahwa sejak lahir anak telah memiliki potensi untuk berkembang. Sebagaimana menurut Mudhofir dalam pengembangan kurikulum di suatu lembaga pendidikan harus memperhatikan asas kejiwaan dan perkembangan peserta didik yaitu; (1) Secara psikologis setiap anak didik memiliki perbedaan baik minat, bakat maupun potensi yang dimilikinya, walaupun secara fisik mungkin saja ada dua atau lebih anakanak yang sama, namun secara psikis antar mereka sebenarnya tidak sama. (2) Anak adalah organisme yang sedang berkembang, yang setiap tahapan perkembangannya memiliki karakteristik dan ciri-ciri tertentu yang iramanya tidak sama atara satu dengan lainnya. Berdasarkan karakteristik dan ciri-ciri 


\section{2 ][ Pengembangan Kurikulum PAl Berbasis Multikultural}

itulah setiap anak harus menyelesaikan tugas-tugas perkembangannya. Sebab manakala tugas pada satu tahap tidak terselesaikan dengan baik, maka perkembangan pada tahap berikutnya akan terganggu. Dengan begitu tujuan, isi, strategi dan metode pembelajaran anak harus dirancang sesuai dengan taraf perkembangannya. ${ }^{40}$ Selanjutnya menurut Arifin masing-masing peserta didik mempunyai tempo perkembangan tersendiri. Oleh karena itu pendidik mempunyai beberapa tugas, yaitu (1) mempelajari perkembangan peserta didik supaya dapat memberikan metode belajar yang sesuai dengan kemampuannya, (2) mempersiapkan kegiatan belajar yang sesuai dengan kemampuannya, (3) mempercepat kemampuan yang lambat. ${ }^{41}$

Implementasi dari hal tersebut terhadap pengembangan kurikulum PAI Multikultural misalnya dalam menanamkan nilai demokrasi, humanis, kesetaraan, dan kebersamaan, antara lain;

(1) Tiap anak diberi kesempatan untuk mengembangkan dan mengaktualisasikan diri sesuai dengan bakat, minat, dan kebutuhannya;

(2) Selain disediakan pembelajaran yang bersifat umum (program inti) yang harus dipelajari oleh setiap peserta didik di sekolah, disediakan pula pembelajaran pilihan sesuai minat dan bakat anak;

(3) menyediakan bahan ajar yang bersifat kejuruan juga menyediakan bahan ajar yang bersifat akademik;

(4) Kurikulum memuat tujuan yang mengandung pengetahuan, nilai/sikap, dan keterampilan yang menggambarkan keseluruhan pribadi yang utuh lahir dan batin.

\section{KESIMPULAN}

Dari paparan di atas, dapat ditarik beberapa kesimpulan bahwa:

1. Teori belajar yang melandasi terhadap pengembangan kurikulum, antara lain sebagai berikut (a) Psikologi Daya, (b) Teori mental State, (c) Psikologi Behaviorisme, (d) Teori Koneksionisme, (e) Psikologi Gestalt, (f) Teori Belajar Konstruktivisme, dan (g) Teori Perkembangan Kognitivisme Jean Piaget.

Gaya belajar dibagi menjadi tiga macam, yaitu gaya belajar Visual, gaya belajar Auditorial, dan gaya belajar Kinestetik. Gaya belajar Visual

\footnotetext{
${ }^{40}$ Ali Mudlofir, Aplikasi Pengembangan KTSP dan Bahan Ajar dalam Pendidikan Agama Islam (Jakarta: Raja Grafindo Persada, 2011), 26.

${ }^{41}$ Zainal Arifin, Konsep dan Model Pengembangan Kurikulum, (Bandung: PT Remaja Rosda Karya, 2013), hlm. 65
} 
adalah belajar dengan cara melihat. Gaya belajar Auditorial adalah belajar dengan cara mendengar. Sedangkan gaya belajar Kinestetik adalah belajar dengan cara bergerak, bekerja, dan menyentuh.

2. Langkah-langkah dalam Pengembangan Kurikulum PAI berbasis Multikultural pada madrasah dapat dilakukan berdasarkan langkahlangkah sebagai berikut; (1) Teori belajar yang digunakan dalam kurikulum yang memperhatikan keragaman sosial, budaya, ekonomi, dan politik tidak boleh lagi hanya mendasarkan diri pada teori psikologi belajar yang menempatkan siswa sebagai makhluk sosial, budaya, politik, yang hidup sebagai anggota aktif masyarakat, bangsa, dan dunia yang harus diseragamkan oleh institusi pendidikan. (2) Proses belajar yang dikembangkan untuk siswa haruslah pula berdasarkan proses yang memiliki tingkat isomorphisme yang tinggi dengan kenyataan sosial.

Desain Pengembangan Kurikulum PAI Multikultural berlandaskan psikologi belajar siswa dalam menanamkan nilai demokrasi, humanis, kesetaraan, dan kebersamaan, antara lain;

a. Tiap anak diberi kesempatan untuk mengembangkan dan mengaktualisasikan diri sesuai dengan bakat, minat, dan kebutuhannya;

b. Selain disediakan pembelajaran yang bersifat umum (program inti) yang harus dipelajari oleh setiap peserta didik di sekolah, disediakan pula pembelajaran pilihan sesuai minat dan bakat anak;

c. Menyediakan bahan ajar yang bersifat kejuruan juga menyediakan bahan ajar yang bersifat akademik;

d. Kurikulum memuat tujuan yang mengandung pengetahuan, nilai/sikap, dan keterampilan yang menggambarkan keseluruhan pribadi yang utuh lahir dan batin.

\section{DAFTAR PUSTAKA}

Ahmadi, Abu dkk. 2004. Psikologi Belajar, Jakarta: Rineka Cipta.

Ali Mudlofir, 2011. Aplikasi Pengembangan KTSP dan Bahan Ajar dalam Pendidikan Agama Islam. Jakarta: Raja Grafindo Persada.

Baidhawy, Zakiyuddin. 2005. Pendidikan Agama Berwawasan Multikultural, Jakarta: Erlangga

Banks, J.A..Multicultural Education: Its Effects on Studies' Racial abd 
274 ][ Pengembangan Kurikulum PAI Berbasis Multikultural

Gender Role Attitude" In Handbook of Research on Social Teaching and Learning. (New York.: MacMillan, 1993) dalam http://lubisgrafura.wordpress.com/2007/09/10/pembelajaranberbasis-multikultural/

Bobby DePorter dan Mike Hernacki, 2010. Quantum Learning: Membiasakan Belajar Nyaman dan Menyenangka. Bandung: KAIFA Colin Rose,dkk. 2002. Accelerated Learning for $21^{\text {st }}$ Century .Bandung: Nuansa.

Farid Hasyim. 2013. Kurikulum Pendidikan Agama Islam: Filosofis Pengembangan Kurikulum Transformatif antara KTSP dan Kurikulum 2013. Malang: Madani.

Ghony, Djunaidi. 2016-2017. 'Desain Pengembangan Kurikulum Pendidikan Agama Islam Multikultural (Handbook Program Doktor PAI Multikultural). Malang: UNISMA

Gordon Dryden,dkk, , 2001. Revolusi Cara Belajar (The Learning Revolution) Belajar akan Efektif Kalau Anda dalam Keadaan "Fun" Bandung: Kaifa.

H.A.R. Tilaar. 2003. Multikulturalisme, Tantangan-Tantangan Global Masa Depan dalam Transformasi Pendidikan Nasional.Jakarta: PT Grasindo, 2003.

Hamalik Oemar.2013. Dasar-Dasar pengembangan Kurikulum. Bandung: Remaja Rosdakarya.

Hasan S. Hamid. 2000. Multikultural untuk Penyempurnaan Kurikulum Nasional, Jurnal Pendidikan dan Kebudayaan,

Hidayat, Sholeh. 2015. Pengembangan Kurikulum Baru. Bandung. Remaja Rosdaakarya.

Nasution, 2006. Berbagai Pendekatan dalam Proses Belajar dan Mengajar .Jakarta: Bumi Aksara.

Sia Tjundjing. 2003. "Keandalan VARK: Instrumen Modalitas Belajar Baru yang Unik dan Menarik",Anima, Indonesian Psychological Journal .Vol. 18, No. 4, Juli 2003

Sugiyono dkk,. 2011. Belajar dan Pembelajaran: Teori dan Praktik. Bandung: Remaja Rosdakarya.

Susanto, Edi et.al., 2008. Pendidikan Agama Islam Multikultural; Perspektif Kritis atas Pemikiran Nurcholish Madjid. Surabaya: Penerbit eLKAF. 